\title{
Effect of simulated environmental change on alpine soil arthropods
}

\author{
SIGMUND H A G VAR and KARI KLANDERUD \\ Department of Ecology and Natural Resource Management, Norwegian University of Life Sciences, PO Box 5003, NO-1432 Aas, \\ Norway
}

\begin{abstract}
The effects of environmental change on soil animal communities are poorly known. Norwegian mountains are subject to both atmospheric nitrogen deposition and increased temperature. In a nutrient poor alpine Dryas heath in south Norway, soil arthropods were studied after 4 years of simulated environmental change by warming and/or nutrient addition. Warming alone only affected three low-density Collembola species, while nutrient addition, with or without warming, greatly changed the dominance hierarchy of the microarthropod community. Certain Collembola species with a short (1 year) life cycle and predatory Gamasina mites increased markedly in density. These groups may have been favored by increased litter production, as plant biomass and litter producing graminoids and forbs increased significantly in plots with nutrient addition and nutrient addition combined with warming. Microarthropods with a longer life cycle, such as Oribatida and certain Collembola, were generally unaffected by nutrient addition and probably need more time to respond. The number of Oribatida taxa was, however, reduced in plots with nutrient addition, both with and without warming. A groundliving species of Coccoidea (Homoptera) declined in plots with nutrient addition and warming compared with only warming, probably due to reduced cover of its host plant Dryas. The density of Diptera larvae (Sciaridae and Chironomidae) was unaffected by the treatments. Our results show that increased nutrient availability in nutrient poor alpine soils may have large but different effects on different taxa of soil animals. Species with short life cycles reacted first. Nutrient addition and nutrient addition combined with warming resulted in several effects below ground on microarthropods as previously shown above ground on plants: Increased biomass, high dominance of a few rapidgrowing species, contrasting responses of closely related species, and a reduction in species numbers. These short-term responses may have profound long-term effects in this alpine ecosystem.
\end{abstract}

Keywords: Alpine tundra, below-ground changes, nutrient increase, soil-living arthropods, temperature change

Received 6 November 2008; revised version received 3 March 2009 and accepted 10 March 2009

\section{Introduction}

The first effects of climate change are likely to be observed in terrestrial habitats at northern latitudes (IPCC, 2007). A marked temperature increase has been noted during the last 2-3 decades in alpine areas of southern Norway where glaciers and snow fields recede (Ytrehus et al., 2008). A key factor for ecosystem responses may be changes in soil processes, which

Correspondence: Sigmund Hågvar, tel. + 4791714510 or +4764 9657 51, fax + 47649658 01, e-mail: sigmund.hagvar@umb.no regulate the availability of plant nutrients (e.g., Dormann \& Woodin, 2002). As long as moisture does not become limiting, it is assumed that increased temperature will enhance $\mathrm{N}$ mineralization, and thus increase the availability of nutrients for plants (Anderson, 1992; Nadelhoffer et al., 1992; Lloyd \& Taylor, 1994; White et al., 1999). Furthermore, Norway and northwestern Europe are influenced by a constant deposition of longdistance transported atmospheric nitrogen (Hole \& Engardt, 2008). Fertilization effects are most probable in nutrient-deficient ecosystems, such as alpine habitats with poorly developed soils. 
Environmental change due to warming and/or increased nutrient availability may affect alpine soil organisms in several ways: direct responses to changes in temperature, moisture or food availability, indirect responses due to changes in competitive relationships, or more long-term effects due to permanent changes in root systems and litter quantity and quality following vegetation changes. Among the soil animals participating in decomposition processes is the species-rich group of microarthropods, encompassing various groups of Collembola (springtails) and Acari (mites) (e.g., Seastedt, 1984; Verhoef \& de Goede, 1985; Mebes \& Filser, 1998).

Experiments with increased temperatures in high arctic soils on Svalbard have shown variable effects on microarthropods. Dollery et al. (2006) recorded a reduced abundance of Collembola, while two groups of Acari, Cryptostigmata and predatory mites, increased. A possible explanation was that Collembola were sensitive to drier conditions created by higher temperatures. Other studies on Svalbard have shown either no effect of warming on microarthropods, or a mixture of negative and positive effects on Collembola (Coulson et al., 1996; Hodkinson et al., 1996; Hodkinson et al., 1998; Webb et al., 1998). Hodkinson et al. (1998) concluded that the common species of arctic soil mites and Collembola are well adapted to survive enhanced summer temperatures, providing that moisture is not limited. They pointed, however, to increased freeze-thaw events as a possible critical factor in the life history of microarthropods.

Warming experiments in the Antarctic region have given contradictory results on microarthropod groups (Kennedy, 1994; Convey et al., 2002; Sinclair, 2002; McGeoch et al., 2006). In a review, Sinclair \& Stevens (2006) concluded that current evidence of climatic change on Antarctic microarthropods is equivocal, but they pointed to reduced soil moisture as a potential problem if temperature increases. They also stressed that to predict effects of climate change on microarthropods, there is a need for increased knowledge in dispersal ability and population and community ecology.

Close connections may exist between vegetation and soil fauna, and soil fauna may respond differently to environmental changes in different vegetation types. For instance, the effect of warming on high arctic Collembola may depend on vegetation type (Coulson et al., 1996; Hodkinson et al., 1998). Coulson et al. (2003) showed that under natural conditions on Svalbard, soil microarthropod communities were influenced by plant species within the vegetation mosaic. One possible explanation was that the rhizosphere microflora on which microarthropods feed differed among plant species.
To our knowledge, only one study exists on the effects of both warming and nutrient addition on soil microarthropods. This was under subarctic conditions near Abisko in northern Sweden (Sjursen et al., 2005), where nutrient addition, with or without warming, increased the abundance of most microarthropod groups. Warming alone, on the other hand, favored oribatid mites but reduced Collembola and Gamasina mites.

Our study is from an alpine Dryas heath near Finse on Hardangervidda in southern Norway. Alpine habitats have been little studied with respect to soil fauna and climatic change. Furthermore, Dryas heaths are widespread in the holarctic and in northern alpine areas. Soil samples were taken in plots where effects of simulated environmental change on the vegetation had been studied (Klanderud \& Totland, 2005; Klanderud, 2008). The design included control plots, warming, nutrient addition, and a combination of warming and nutrient addition. Four years of increased temperature at alpine Finse showed only small effects on plant community composition (Klanderud, 2008) and diversity (Klanderud \& Totland, 2005). Nutrients, however, changed the previously low stature and species-rich Dryas heath to a less diverse community dominated by tall grasses and forbs. Warming combined with nutrient addition resulted in a still taller vegetation canopy consisting mainly of grasses (Klanderud \& Totland, 2005; Klanderud, 2008). This situation was a good opportunity to compare above- and below-ground biotic effects of the environmental changes. Thus, soil samples for microarthropods were taken in 2004, when marked changes in vegetation were evident, to examine (1) if warming and/or nutrient addition had any effects on soil arthropod species richness and density, (2) if such effects differed among soil animal taxa (Collembola, Oribatida), and (3) if responses in the soil fauna community below ground reflected the observed plant community responses above ground.

\section{Materials and methods}

The study site was a Dryas octopetala heath on a southwest exposed slope at about $1500 \mathrm{~m}$ elevation near Finse at Hardangervidda, the alpine region of southwestern Norway. During June, July, and August, the mean monthly temperature at $1200 \mathrm{~m}$ elevation at Finse is $6.3^{\circ} \mathrm{C}$ (Aune, 1993), and the mean monthly precipitation is $89 \mathrm{~mm}$ (Førland, 1993). For detailed habitat descriptions and experimental layout, see Klanderud \& Totland (2005). Ten randomized blocks contained four treatments each: control ( $\mathrm{C}$, no treatment), temperature treatment $(\mathrm{T})$, nutrient addition $(\mathrm{N})$, and temperature plus nutrient addition (TN). The four treatments were 
randomly allocated to four randomly positioned $1 \times 1 \mathrm{~m}$ plots, ca. $1 \mathrm{~m}$ apart from each other, within each block. Hexagonal open-top chambers (OTCs, Marion et al., 1997; Hollister \& Webber, 2000) with a diameter of $1 \mathrm{~m}$ were used to increase temperature. The yearly addition of slow-released granular NPK fertilizer was $10 \mathrm{~g} \mathrm{~N} \mathrm{~m}^{-2}$, $2 \mathrm{~g} \mathrm{Pm}^{-2}$, and $8 \mathrm{~g} \mathrm{Km}^{-2}$. The treatments started in early July 2000, and soil microarthropods were sampled 4 years later (3 and 10 July 2004). The OTCs increased the mean air temperature $5 \mathrm{~cm}$ above the ground by $1.5^{\circ} \mathrm{C}$, and the mean soil temperature at $5 \mathrm{~cm}$ depth by $1.0^{\circ} \mathrm{C}$. Changes in vegetation in late August 2003 were described by Klanderud \& Totland (2005) and Klanderud (2008).

In the center of each of the 40 experimental plots, eight soil samples were taken, $3 \mathrm{~cm}$ deep and with a surface area of $10 \mathrm{~cm}^{2}$. They were extracted for microarthropods according to standard procedure in a highgradient apparatus, modified after Macfadyen (1961). The extraction also gave material of terrestrial Diptera larvae, and of ground-living Coccoidea (Homoptera). In a proglacial area in the high Arctic, Hodkinson et al. (2004) found that heat extraction was more efficient than O'Connor's (1962) wet extraction for terrestrial larvae of Chironomidae, but the general value of this comparison is uncertain. The efficiency of heat extraction on other Diptera larvae (Sciaridae) is unknown, and so numbers should be regarded as relative. Similar extraction methods have earlier been used for Coccoidea (Kozár \& Miller, 2000). Microarthropods were identified to species as far as possible. Nomenclature of Oribatida is according to Weigmann (2006) and of Collembola according to Fjellberg (1998, 2007).

To examine the treatment effects on the density (individuals $\mathrm{m}^{-2}$ ) of each of the soil arthropod taxa separately, and on the species richness of Oribatida and Collembola (dependent variables), we used treatment (four levels: C, T, N, and TN) as a fixed factor and block as a random factor in a randomized block design in general linear models (GLMs) ANOVAs. One analysis was done for each of the dependent variables. We used Tukey's HSD post hoc test to examine significant differences between treatment means. Response variables were log transformed before analyses to ensure normality and equal variances. Taxa that did not fulfill model assumptions after transformation were analyzed for treatment effects only by nonparametric Kruskal-Wallis tests, and pairwise multiple comparisons were performed by the nonparametric Student-Newman-Keuls method. We used a polynomial regression $(f=y 0+$ $\left.a x+b x^{2}\right)$ to examine the relationship between the density of Gamasidae (predictor) and Collembola. All analyses were done in SYSTAT 10.

\section{Results}

Table 1 shows treatment and block effects for the density of microarthropods, Coccoidea, and Diptera larvae. Significant response to temperature treatment alone was found in only three low-density Collembola species: an increase in Micranurida forsslundi and Isotoma sp., and a decrease in Tetracanthella wahlgreni. The latter responded negatively to all the treatments. All other responses were due to nutrient addition, usually with similar responses to nutrients alone and nutrients combined with warming. At the group level, nutrients increased densities of Collembola, as well as Gamasina mites, including the subgroups Gamasidae and Zerconidae. The following Collembola species increased in density after nutrient addition: Folsomia quadrioculata, Parisotoma notabilis, Isotoma viridis, Protaphorura pseudovanderdrifti, and 'Other Sminthuridae'. Micranurida pygmaea increased in fertilized plots without warming. Desoria tolya, Lepidocyrtus lignorum, and Ceratophysella scotica increased in plots with both nutrient addition and warming. Only two oribatid species responded to the treatments: Oribatula tibialis increased, while Fuscozetes sp. decreased in plots with nutrient addition combined with warming. Other mites, including the abundant group of Actinedida, did not respond to any of the treatments (Table 1).

The species of Coccoidea, Arctorthezia cataphracta, decreased in plots with nutrient addition, and in plots with nutrient addition combined with warming, compared with plots with only warming (Table 1). The density of soil-living Diptera larvae (Sciaridae and Chironomidae) was, however, unaffected by the treatments (Table 1).

The mean species number of Oribatida decreased in plots with nutrient addition and in plots with warming combined with nutrient addition $\left(F_{3,27}=4.11\right.$, $P=0.016)$. This was due to a reduced number of rare species. However, the number of Collembola species did not change in any of the treatments $\left(F_{3,27}=2.00\right.$, $P=0.138$ ) (Fig. 1).

There was a nonlinear relationship between the density of Gamasidae mites and Collembola, with an increase in both groups up to a certain level, followed by a flattening of the curve when Gamasidae densities became high (Fig. 2).

Figure 3 illustrates how the dominance structure of the Collembola community was strongly changed by nutrient addition and warming combined with nutrient addition. F. quadrioculata increased its dominance fivefold, from about $10 \%$ to about $50 \%$ of total Collembola numbers. Its close relative, Folsomia brevicauda, however, fell in dominance from about $30 \%$ to one-fifth of that. This change occurred at the same time as the total 
Table 1 Mean density (thousands $\mathrm{m}^{-2} \pm \mathrm{SE}$ ) of various soil arthropods in control $(\mathrm{C})$, warming (T), nutrient addition (N), and warming combined with nutrient addition (TN) plots at Finse, alpine southern Norway

\begin{tabular}{|c|c|c|c|c|c|c|c|c|}
\hline \multirow[b]{2}{*}{ Taxa } & \multirow[b]{2}{*}{$\mathrm{C}$} & \multirow[b]{2}{*}{$\mathrm{T}$} & \multirow[b]{2}{*}{$\mathrm{N}$} & \multirow[b]{2}{*}{$\mathrm{TN}$} & \multicolumn{2}{|c|}{ Treatment } & \multicolumn{2}{|l|}{ Block } \\
\hline & & & & & $F / K$ & $P$ & $F / K$ & $P$ \\
\hline Oribatida & $15.28 \pm 2.07$ & $14.79 \pm 1.40$ & $19.81 \pm 4.29$ & $18.98 \pm 4.33$ & 1.01 & 0.403 & 3.78 & 0.003 \\
\hline Brachychthoniidae & $6.3 \pm 0.94$ & $6.04 \pm 1.23$ & $10.48 \pm 3.10$ & $6.98 \pm 2.03$ & 0.90 & 0.453 & 4.98 & $<0.001$ \\
\hline Tectocepheus velatus ad. & $0.79 \pm 0.13$ & $0.60 \pm 0.18$ & $0.80 \pm 0.31$ & $0.66 \pm 0.23$ & 0.26 & 0.853 & 3.86 & 0.003 \\
\hline Tectocepheus velatus juv. & $1.66 \pm 0.23$ & $1.48 \pm 0.27$ & $2.20 \pm 1.01$ & $1.55 \pm 0.66$ & 0.55 & 0.652 & 5.17 & $<0.001$ \\
\hline Tectocepheus velatus tot. & $2.37 \pm 0.40$ & $2.09 \pm 0.41$ & $2.99 \pm 1.31$ & $2.20 \pm 0.87$ & 0.60 & 0.619 & 5.09 & $<0.001$ \\
\hline Camisia sp. ad. & $0.10 \pm 0.03$ & $0.12 \pm 0.03$ & $0.08 \pm 0.05$ & $0.05 \pm 0.03$ & 4.14 & 0.247 & & \\
\hline Camisia sp. juv. & $0.25 \pm 0.10$ & $0.21 \pm 0.07$ & $0.09 \pm 0.05$ & $0.11 \pm 0.04$ & 1.46 & 0.247 & 1.41 & 0.233 \\
\hline Camisia sp. tot. & $0.36 \pm 0.12$ & $0.33 \pm 0.08$ & $0.16 \pm 0.10$ & $0.17 \pm 0.06$ & 1.90 & 0.153 & 2.42 & 0.037 \\
\hline Platynothrus sp. & $0.06 \pm 0.04$ & $0.03 \pm 0.02$ & 0 & $0.19 \pm 0.13$ & & & & \\
\hline Nothrus borussicus & $0.04 \pm 0.04$ & 0 & $0.01 \pm 0.01$ & 0 & & & & \\
\hline Oppia sp. & $0.25 \pm 0.12$ & $0.01 \pm 0.01$ & $0.10 \pm 0.05$ & $0.11 \pm 0.07$ & & & & \\
\hline Quadroppia quadricarinata & $0.93 \pm 0.40$ & $1.70 \pm 0.28$ & $1.66 \pm 0.55$ & $0.84 \pm 0.40$ & 2.87 & 0.055 & 1.87 & 0.100 \\
\hline Suctobelba sp. & $0.01 \pm 0.01$ & 0 & 0 & 0 & & & & \\
\hline Belba sp. & 0 & 0 & 0 & $0.01 \pm 0.01$ & & & & \\
\hline Phthiracaridae & $0.18 \pm 0.09$ & $0.19 \pm 0.12$ & $0.11 \pm 0.06$ & $0.13 \pm 0.04$ & 0.71 & 0.871 & & \\
\hline Carabodes sp. & $0.04 \pm 0.04$ & 0 & 0 & 0 & & & & \\
\hline Mycobates sp. & $0.24 \pm 0.12$ & $0.09 \pm 0.04$ & 0 & $0.08 \pm 0.08$ & & & & \\
\hline Oromurcia sp. & 0 & $0.01 \pm 0.01$ & 0 & 0 & & & & \\
\hline Fuscozetes sp. & $0.61 \pm 0.34^{\mathrm{a}}$ & $0.26 \pm 0.01^{\mathrm{ab}}$ & $0.10 \pm 0.06^{\mathrm{ab}}$ & $0^{\mathrm{b}}$ & 11.06 & 0.011 & & \\
\hline Oribatula tibialis & $0.59 \pm 0.13^{\mathrm{a}}$ & $1.45 \pm 0.37^{\mathrm{ab}}$ & $0.63 \pm 0.17^{\mathrm{a}}$ & $2.76 \pm 0.77^{\mathrm{b}}$ & 4.18 & 0.015 & 1.60 & 0.165 \\
\hline Eupelops sp. ad. & $0.35 \pm 0.17$ & $0.32 \pm 0.10$ & $0.49 \pm 0.15$ & $0.28 \pm 0.07$ & 2.10 & 0.552 & & \\
\hline Eupelops sp. juv. & $0.89 \pm 0.39$ & $0.30 \pm 0.09$ & $1.05 \pm 0.40$ & $0.40 \pm 0.14$ & 2.01 & 0.136 & 1.94 & 0.088 \\
\hline Eupelops sp. tot. & $1.24 \pm 0.54$ & $0.62 \pm 0.18$ & $1.54 \pm 0.53$ & $0.68 \pm 0.20$ & 2.99 & 0.393 & & \\
\hline Oribatida juv. & $2.05 \pm 0.68$ & $1.97 \pm 0.51$ & $2.01 \pm 0.70$ & $4.83 \pm 1.63$ & 1.03 & 0.395 & 2.03 & 0.075 \\
\hline Gamasina & $2.45 \pm 0.44^{\mathrm{a}}$ & $2.30 \pm 0.50^{\mathrm{a}}$ & $6.48 \pm 0.73^{\mathrm{b}}$ & $6.21 \pm 0.55^{\mathrm{b}}$ & 22.74 & $<0.001$ & 1.75 & 0.126 \\
\hline Gamasidae ad. & $0.47 \pm 0.10^{\mathrm{a}}$ & $0.36 \pm 0.08^{\mathrm{a}}$ & $1.00 \pm 0.21^{\mathrm{b}}$ & $0.89 \pm 0.09^{\mathrm{b}}$ & 8.23 & $<0.001$ & 1.86 & 0.102 \\
\hline Gamasidae juv. & $1.24 \pm 0.32^{\mathrm{a}}$ & $1.03 \pm 0.19^{\mathrm{a}}$ & $3.28 \pm 0.60^{\mathrm{b}}$ & $2.60 \pm 0.42^{\mathrm{b}}$ & 11.38 & $<0.001$ & 2.25 & 0.050 \\
\hline Gamasidae tot. & $1.71 \pm 0.37^{\mathrm{a}}$ & $1.38 \pm 0.24^{\mathrm{a}}$ & $4.27 \pm 0.72^{\mathrm{b}}$ & $3.49 \pm 0.44^{\mathrm{b}}$ & 18.18 & $<0.001$ & 3.36 & 0.007 \\
\hline Zerconidae ad. & $0.14 \pm 0.06^{\mathrm{a}}$ & $0.20 \pm 0.08^{\mathrm{ab}}$ & $0.48 \pm 0.11^{\mathrm{b}}$ & $0.65 \pm 0.28^{\mathrm{b}}$ & 9.19 & 0.027 & & \\
\hline Zerconidae juv. & $0.60 \pm 0.11^{\mathrm{a}}$ & $0.71 \pm 0.27^{\mathrm{a}}$ & $1.74 \pm 0.34^{\mathrm{b}}$ & $2.07 \pm 0.42^{\mathrm{b}}$ & 6.40 & 0.002 & 0.49 & 0.870 \\
\hline Zerconidae tot. & $0.74 \pm 0.10^{\mathrm{a}}$ & $0.91 \pm 0.31^{\mathrm{a}}$ & $2.22 \pm 0.38^{\mathrm{b}}$ & $2.72 \pm 0.58^{\mathrm{b}}$ & 7.74 & 0.001 & 0.33 & 0.957 \\
\hline Other mites & $24.59 \pm 4.16$ & $31.77 \pm 4.49$ & $38.95 \pm 8.88$ & $33.07 \pm 4.81$ & 0.95 & 0.431 & 0.58 & 0.798 \\
\hline Uropodina & $0.19 \pm 0.17$ & $0.03 \pm 0.03$ & $0.23 \pm 0.17$ & 0 & & & & \\
\hline Mesostigmata indet. & $0.04 \pm 0.04$ & 0 & 0 & 0 & & & & \\
\hline Scutacaridae & $0.01 \pm 0.01$ & $0.01 \pm 0.01$ & $5.47 \pm 5.17$ & $0.63 \pm 0.43$ & & & & \\
\hline Other Actinedida & $24.35 \pm 4.11$ & $31.73 \pm 4.50$ & $33.13 \pm 5.20$ & $32.40 \pm 4.67$ & 0.89 & 0.459 & 0.684 & 0.717 \\
\hline Schwiebea sp. & 0 & 0 & $0.06 \pm 0.06$ & $0.01 \pm 0.01$ & & & & \\
\hline Other Acaridida & 0 & 0 & $0.06 \pm 0.05$ & $0.03 \pm 0.03$ & & & & \\
\hline Collembola & $34.51 \pm 6.7^{\mathrm{a}}$ & $36.01 \pm 6.71^{\mathrm{a}}$ & $129.83 \pm 13.36^{\mathrm{b}}$ & $134.94 \pm 26.35^{\mathrm{b}}$ & 22.35 & $<0.001$ & 1.02 & 0.446 \\
\hline Ceratophysella scotica & $0.06 \pm 0.05^{\mathrm{a}}$ & $0.13 \pm 0.05^{\mathrm{ab}}$ & $0.32 \pm 0.10^{\mathrm{ab}}$ & $0.62 \pm 0.25^{\mathrm{b}}$ & 12.15 & 0.007 & & \\
\hline Willemia sp. & $0.76 \pm 0.26$ & $1.29 \pm 0.35$ & $2.37 \pm 0.85$ & $3.54 \pm 1.86$ & 1.82 & 0.167 & 0.82 & 0.603 \\
\hline Friesea truncata & $0.53 \pm 0.31$ & $0.19 \pm 0.09$ & $0.87 \pm 0.58$ & $0.28 \pm 0.11$ & 0.66 & 0.883 & & \\
\hline Micranurida forsslundi & $0.09 \pm 0.04^{\mathrm{a}}$ & $0.18 \pm 0.05^{\mathrm{b}}$ & $0.09 \pm 0.06^{\mathrm{ab}}$ & $0^{\mathrm{ab}}$ & 8.37 & 0.039 & & \\
\hline Micranurida pygmaea & $0^{\mathrm{a}}$ & $0^{\mathrm{a}}$ & $1.99 \pm 1.56^{\mathrm{b}}$ & $0.93 \pm 0.66^{\mathrm{ab}}$ & 14.60 & 0.002 & & \\
\hline Neanura muscorum & 0 & $0.01 \pm 0.01$ & 0 & 0 & & & & \\
\hline Protaphorura pseudovanderdrifti & $1.25 \pm 0.37^{\mathrm{a}}$ & $1.27 \pm 0.16^{\mathrm{a}}$ & $6.55 \pm 1.23^{\mathrm{b}}$ & $3.35 \pm 0.44^{\mathrm{c}}$ & 19.83 & $<0.001$ & 0.91 & 0.532 \\
\hline Mesaphorura sp. & $6.13 \pm 2.58$ & $15.01 \pm 8.21$ & $5.96 \pm 3.96$ & $5.16 \pm 2.26$ & 2.39 & 0.091 & 3.55 & 0.005 \\
\hline Tetracanthella wahlgreni & $1.02 \pm 0.31^{\mathrm{a}}$ & $0.28 \pm 0.09^{\mathrm{b}}$ & $0.03 \pm 0.03^{\mathrm{b}}$ & $0^{\mathrm{b}}$ & 24.33 & $<0.001$ & & \\
\hline Tetracanthella brachyura & $0.76 \pm 0.33$ & $0.21 \pm 0.10$ & $1.14 \pm 0.48$ & $0.44 \pm 0.30$ & 3.72 & 0.293 & & \\
\hline Pseudanurophorus binoculatus & $0.96 \pm 0.29^{\mathrm{ab}}$ & $0.81 \pm 0.30^{\mathrm{b}}$ & $2.91 \pm 0.74^{\mathrm{a}}$ & $2.27 \pm 1.09^{\mathrm{ab}}$ & 3.08 & 0.044 & 1.62 & 0.160 \\
\hline Isotomodella pusilla & $1.82 \pm 0.57$ & $1.84 \pm 0.64$ & $3.43 \pm 1.22$ & $4.29 \pm 1.68$ & 0.82 & 0.845 & & \\
\hline
\end{tabular}


Table 1. (Contd.)

\begin{tabular}{|c|c|c|c|c|c|c|c|c|}
\hline \multirow[b]{2}{*}{ Taxa } & \multirow[b]{2}{*}{$\mathrm{C}$} & \multirow[b]{2}{*}{$\mathrm{T}$} & \multirow[b]{2}{*}{$\mathrm{N}$} & \multirow[b]{2}{*}{$\mathrm{TN}$} & \multicolumn{2}{|c|}{ Treatment } & \multicolumn{2}{|l|}{ Block } \\
\hline & & & & & $F / K$ & $P$ & $F / K$ & $P$ \\
\hline Folsomia brevicauda & $9.44 \pm 2.87$ & $4.90 \pm 1.65$ & $7.45 \pm 3.45$ & $1.95 \pm 0.89$ & 4.61 & 0.203 & & \\
\hline Folsomia palaearctica & $0.83 \pm 0.79$ & $0.18 \pm 0.18$ & $0.68 \pm 0.68$ & $0.09 \pm 0.06$ & & & & \\
\hline Folsomia dovrensis & 0 & 0 & $0.01 \pm 0.01$ & 0 & & & & \\
\hline Folsomia quadrioculata & $3.05 \pm 1.06^{\mathrm{a}}$ & $2.73 \pm 0.89^{\mathrm{a}}$ & $63.50 \pm 13.95^{\mathrm{b}}$ & $64.40 \pm 18.40^{\mathrm{b}}$ & 20.35 & $<0.001$ & 1.59 & 0.168 \\
\hline Isotomiella minor & $1.25 \pm 0.69$ & $0.33 \pm 0.13$ & $1.76 \pm 0.90$ & $0.32 \pm 0.19$ & 4.56 & 0.207 & & \\
\hline Parisotoma ekmani & $0.10 \pm 0.09$ & $0.17 \pm 0.13$ & $0.36 \pm 0.35$ & $0.95 \pm 0.94$ & & & & \\
\hline Parisotoma notabilis & $3.82 \pm 2.21^{\mathrm{a}}$ & $2.37 \pm 0.60^{\mathrm{a}}$ & $21.91 \pm 4.82^{b}$ & $31.02 \pm 14.65^{\mathrm{b}}$ & 15.26 & $<0.001$ & 1.46 & 0.213 \\
\hline Desoria olivacea & 0 & 0 & $0.01 \pm 0.01$ & $1.47 \pm 1.31$ & & & & \\
\hline Desoria tolya & $0.01 \pm 0.01^{\mathrm{a}}$ & $0^{\mathrm{a}}$ & $0.18 \pm 0.07^{\mathrm{ab}}$ & $0.34 \pm 0.14^{\mathrm{b}}$ & 15.08 & 0.002 & & \\
\hline Isotoma viridis & $1.22 \pm 0.17^{\mathrm{a}}$ & $1.72 \pm 0.35^{\mathrm{a}}$ & $4.08 \pm 0.63^{\mathrm{b}}$ & $4.97 \pm 1.08^{\mathrm{b}}$ & 9.71 & $<0.001$ & 0.81 & 0.614 \\
\hline Isotoma sp. & $0.06 \pm 0.03^{\mathrm{a}}$ & $0.20 \pm 0.06^{\mathrm{b}}$ & $0.01 \pm 0.01^{\mathrm{a}}$ & $0^{\mathrm{a}}$ & 15.69 & 0.001 & & \\
\hline Lepidocyrtus lignorum & $1.01 \pm 0.15^{\mathrm{a}}$ & $1.19 \pm 0.20^{\mathrm{a}}$ & $1.72 \pm 0.24^{\mathrm{a}}$ & $5.31 \pm 0.62^{\mathrm{b}}$ & 35.97 & $<0.001$ & 1.40 & 0.238 \\
\hline Megalothorax minimus & $0.09 \pm 0.05$ & $0.48 \pm 0.22$ & $0.46 \pm 0.24$ & $0.23 \pm 0.11$ & 1.30 & 0.294 & 1.31 & 2.77 \\
\hline Other Sminthuridae & $0.27 \pm 0.18^{\mathrm{a}}$ & $0.51 \pm 0.21^{\mathrm{a}}$ & $2.05 \pm 0.49^{b}$ & $3.02 \pm 1.15^{\mathrm{b}}$ & 16.05 & $<0.001$ & 4.59 & 0.001 \\
\hline Homoptera: Coccoidea & $1.10 \pm 0.78^{\mathrm{ab}}$ & $1.43 \pm 0.59^{\mathrm{b}}$ & $0.08 \pm 0.05^{\mathrm{a}}$ & $0.05 \pm 0.03^{\mathrm{a}}$ & 5.22 & 0.006 & 2.29 & 0.047 \\
\hline Diptera larvae & $0.36 \pm 0.17$ & $0.44 \pm 0.20$ & $0.49 \pm 0.15$ & $0.73 \pm 0.26$ & 0.73 & 0.546 & 1.43 & 0.226 \\
\hline Sciaridae & $0.32 \pm 0.17$ & $0.36 \pm 0.17$ & $0.39 \pm 0.17$ & $0.42 \pm 0.14$ & 0.18 & 0.912 & 1.36 & 0.254 \\
\hline Chironomidae & $0.04 \pm 0.02$ & $0.08 \pm 0.05$ & $0.10 \pm 0.05$ & $0.31 \pm 0.15$ & 4.63 & 0.200 & & \\
\hline
\end{tabular}

General linear model (GLM) $F$ - and $P$-values are shown for treatment and block effects. When variance was heterogeneous and/or normality test failed, only treatment effect was calculated, with Kruskal-Wallis test statistic $(K)$. Degrees of freedom are 3, 27 for the treatment effect and 9, 27 for the block effect. Statistical significant values $(P<0.05)$ are in bold, and differences between treatment means are indicated by different letters (Tukey's HSD or Student-Newman-Keuls method for GLM and Kruskal-Wallis test, respectively). Only taxa that were present in $>5$ plots of at least one of the treatments were tested.

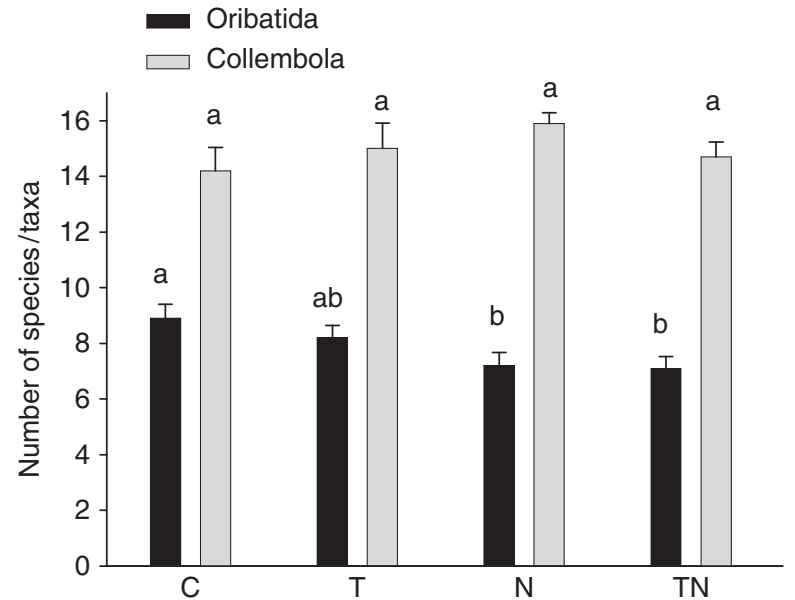

Fig. 1 Species richness of Oribatida and Collembola in control plots $(\mathrm{C})$, plots with warming $(\mathrm{T})$, nutrient addition $(\mathrm{N})$, and warming combined with nutrient addition (TN) at Finse, alpine Norway. Bars with different letters differ significantly $(P<0.05$, Tukey HSD).

density of Collembola increased fourfold in fertilized plots, with and without warming (Table 1). Among Oribatei, however, neither the abundance nor the dominance structure was significantly affected by nutrient addition (Table 1, Fig. 3).

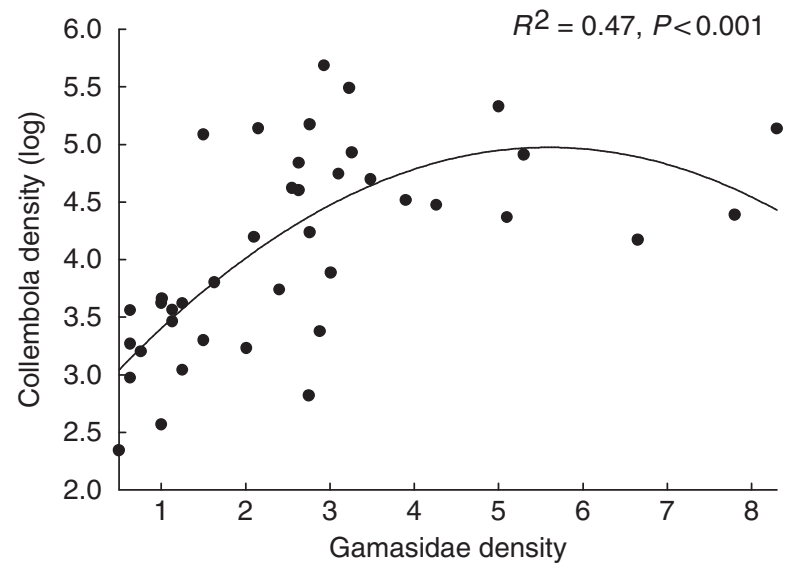

Fig. 2 Polynomial regression of the relationship between the density $\left(1000 \mathrm{~m}^{-2}\right)$ of Collembola and Gamasidae at Finse, alpine Norway.

Block effects were found on the abundance of some taxa (Table 1), indicating differences in soil conditions among blocks. Regarding species richness, there was no block effect for Oribatida $\left(F_{9,27}=1.77, P=0.121\right)$, while a clear block effect was seen in the number of Collembola species $\left(F_{9,27}=3.60, P=0.005\right)$. This was most likely due to differences in the soil organic layer. The 

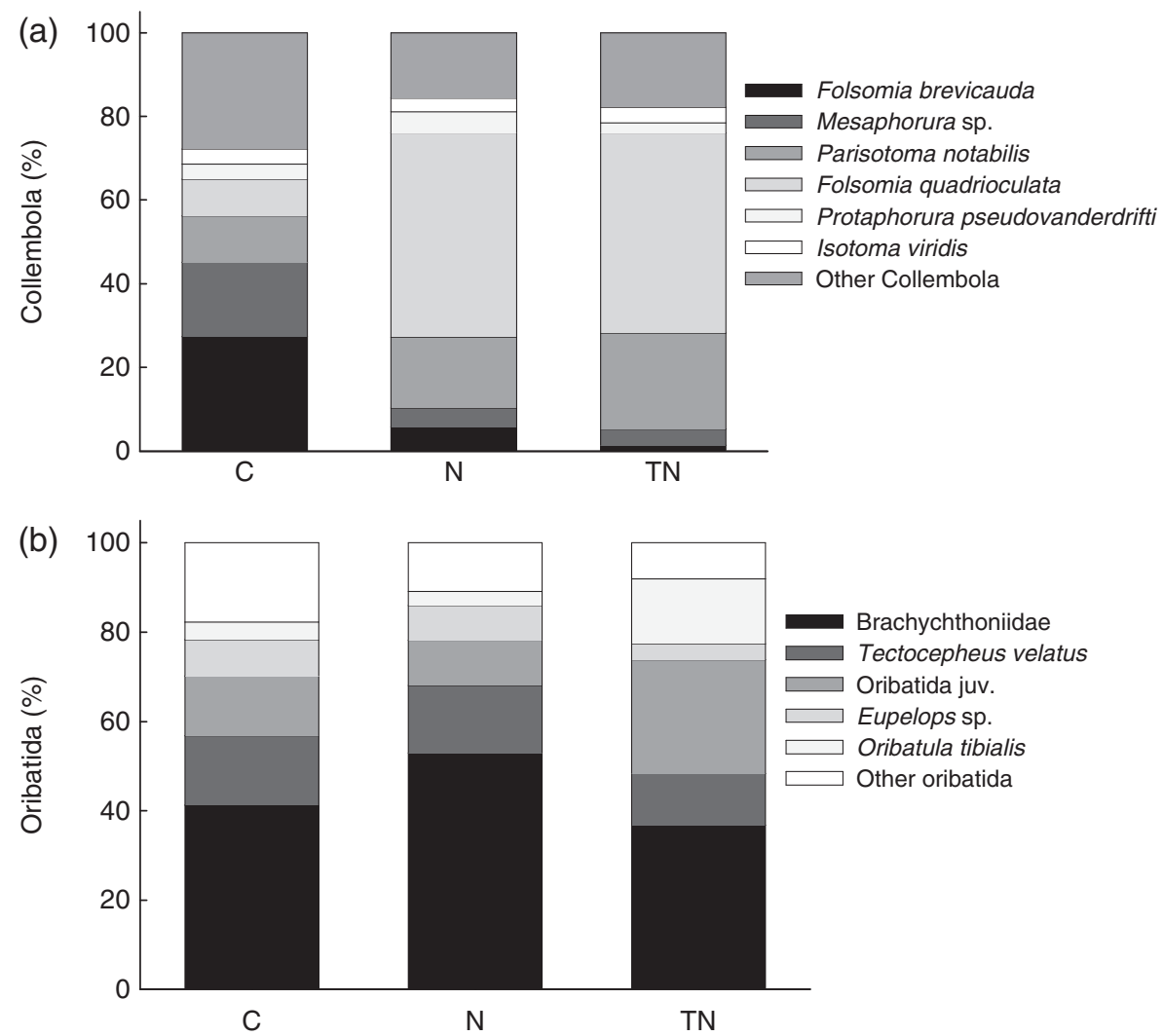

Fig. 3 Dominance structure of the Collembola and the Oribatida community in control plots (C), plots with nutrient addition (N), and warming combined with nutrient addition (TN) at Finse, alpine Norway. Changes between control plots (C) and warmed plots (T) were negligible.

organic content at ca. $5 \mathrm{~cm}$ depth, measured as loss on ignition (LOI) was in the range of ca. 12-20\%, with no significant difference between treatments (GLM ANOVA; $\left.F_{3,27}=0.77, P=0.523\right)$, but with a marginally significant difference between blocks (GLM ANOVA; $F_{9,27}=2.19$, $P=0.056$ ). The highest species number of Collembola was found in those blocks with the highest organic content, i.e. in blocks with the thickest organic layer (K. Klanderud, personal observations), and simple linear regressions showed a positive relationship between the number of Collembola species and LOI across all treatments $\left(R^{2}=0.118, P=0.030\right)$.

\section{Discussion}

Nutrient addition, and warming combined with nutrient addition, led to a profound change in the Collembola community, with most pronounced changes in the TN plots for some of the species. The total Collembola density increased fourfold in $\mathrm{N}$ and TN plots, mainly due to F. quadrioculata and P. notabilis. These two relatively large species are habitat generalists (Hågvar, 1982; Fjellberg, 2007) and live in the uppermost part of the soil profile (Hågvar, 1983). Both species feed partly on fungal hyphae (Bödvarsson, 1970; Hågvar \& Kjøndal, 1981; Chen et al., 1996). In particular F. quadrioculata is a flexible food generalist (Mebes \& Filser, 1998), which in culture eats fungi, green algae, and cyanobacteria (H. P. Leinaas, personal communication). Fertilized plots achieved a completely different vegetation than the $\mathrm{C}$ and $\mathrm{T}$ plots, being dominated by tall graminoids with more biomass and a higher litter production (Klanderud \& Totland, 2005). Thus, a possible explanation for increased collembolan density in fertilized plots is increased food availability due to high fungal activity in decomposing graminoid litter. Also I. viridis and 'Other Sminthuridae' represent large, litter-inhabiting species.

Responses among microarthropods to nutrient addition may also be due to changes in soil chemistry and root systems, as well as competition. Competition may be an important ecological factor in microarthropod communities (e.g., Hågvar, 1990). Combined with low reproduction rates in some species, it may take a long time for the microarthropod community to stabilize after environmental change. 
Species with a short life cycle may respond rapidly to environmental change. In an Antarctic soil heating experiment, Convey \& Wynn-Williams (2002) found a rapid population increase in the microbivorous nematode genus Plectus, which has a short life cycle, resulting in changes in the relative abundance of taxa. According to Fjellberg (1974), F. quadrioculata, P. notabilis, and I. viridis have a 1-year life cycle in the present mountain area, which probably explains their rapid response to nutrient addition. F. brevicauda, however, which dominated the control plots but remained unaffected by nutrient addition, has a 2-year life cycle and needs more time to respond. That is also the case with the two Tetracanthella species. The nearly unchanged Oribatida community after 4 years of nutrient addition is probably due to life cycles spanning 2 or more years. These mites with their low metabolic rates, slow development, and low fecundity cannot respond rapidly to resource flushes (Behan-Pelletier, 1999). Even in a lowland Danish beech forest, Luxton (1981) found that some oribatids developed slowly, with life cycles of 1-2 years. In colder climates, Oribatida often have multiyear life cycles (Walter \& Proctor, 1999). In Austrian mountains, Oromurcia sudetica has a 2-3 year, or possibly 4-year life cycle (Schatz, 1985). On the Hardangervidda, even the small Tectocepheus velatus is assumed to use 2 or more years to fulfill the life cycle (Solhøy, 1975), and Tilrem (1994) assumed a development time of 4-6 years for Ameronothrus lapponicus living in lichens on erratic boulders at Finse. The significant reduction of species richness of Oribatida in $\mathrm{N}$ and TN plots is due to the absence of some rare species and may indicate the beginning of a decline in biodiversity.

The increased abundance of predatory Gamasina mites in fertilized plots is probably due to increased prey abundance. These active mites live high in the soil profile, often in the litter. Gamasidae feed on a variety of animals, including Collembola (Wallwork, 1970). Zerconidae are known to prey on Nematoda (Martikainen \& Huhta, 1990). In a similar experiment in two subarctic soils, Ruess et al. (1999) found that nematode populations increased in fertilized plots, also in combination with warming, compared with control plots.

Diptera larvae tended to be more abundant on fertilized plots than in the controls, although not significant. A. cataphracta (Coccoidea), on the other hand, was reduced by nutrient addition combined with warming, compared with only warming. This holarctic species lives on the ground, feeding on roots of several plants, among them Dryas (Kosztarab \& Kozár, 1988). Dryas abundance decreased significantly in the TN plots (Klanderud \& Totland, 2005), which may explain the decline of this species.
Theoretically, soil arthropods may have migrated in or out of the OTCs during the experiment. However, the population increase in species with a short life cycle compared with species with a long life cycle is consistent with a response within the OTC. Furthermore, the soil samples were taken in the central part of each OTC.

Four years of warming may be too short to reveal clear biological effects, both above and below ground. The responses in three low-density Collembola are difficult to interpret. Warming hardly affected vegetation structure, except for a reduced abundance of some bryophyte species (Klanderud \& Totland, 2005; Klanderud, 2008), which was most likely due to a drier soil surface (K. Klanderud, unpublished results). Similar warming studies on soil animals have revealed several practical problems. Firstly, increased drought in warmed plots has been a general side effect in these types of experiments, both in Arctic and Antarctic habitats, and Collembola are especially vulnerable to drought stress (summaries by Hodkinson et al., 1998; Sinclair \& Stevens, 2006). Secondly, climatic differences between years may mask treatment effects on microarthropods (e.g., Coulson et al., 1996). Moreover, the modifying effect of local soil moisture was shown in a subalpine meadow in the Rocky Mountains, as the effect of warming on soil animals depended on whether the summer was cool and wet, or warm and dry (Harte et al., 1996). The lower number of Collembola species in blocks with a thinner organic layer in the present study may be due to drier surface conditions.

Studies on environmental change are most often limited to above-ground effects. However, both from an ecosystem function and biodiversity point of view, below-ground changes are crucial. In this study, certain effects of nutrient addition were common for belowground arthropods and above-ground vegetation (Klanderud \& Totland, 2005; Klanderud, 2008): increased biomass, high dominance of a few species, reduction in species number, and different responses in closely related species. Further studies in other alpine areas are needed to check the general value of this pattern.

The present study has shown that the soil arthropod community in nutrient poor alpine sites can be sensitive to increased nutrients, likely due to changes in associated vegetation. Microarthropod species with short life cycles can take over the dominance after few years, before species with longer life cycles are able to react. The reduced diversity of slowly reproducing Oribatida may be a result of competition with rapidly expanding Collembola populations. Further community changes may be expected when species with longer life cycles have had the possibility to respond. Nutrient addition in the present ecosystem has triggered processes both above and below ground, which may take many years to stabilize. 


\section{Acknowledgements}

Carl-Axel Gertsson is heartily thanked for identifying the species of Coccoidea, Geir E. E. Søli for identifying the larvae of Sciaridae, and Hans Petter Leinaas for information about food choice in F. quadrioculata. Thanks to Finse research station for hospitality.

\section{References}

Anderson JM (1992) Responses of soils to climate change. Advances in Ecological Research, 22, 163-210.

Aune B (1993) Temperaturnormaler: Normalperiode 1961-1990. Det Norske meteorologiske institutt, Oslo, Norway.

Behan-Pelletier VM (1999) Oribatid mite biodiversity in agroecosystems: role for bioindication. Agriculture, Ecosystems and Environment, 74, 411-423.

Bödvarsson H (1970) Alimentary studies of seven common soilinhabiting Collembola of Southern Sweden. Entomologica Scandinavica, 1, 74-80.

Chen B, Snider RJ, Snider RM (1996) Food consumption by Collembola from northern Michigan deciduous forest. Pedobiologia, 40, 149-161.

Convey P, Pugh PJA, Jackson C, Murray AW, Ruhland CT, Xiong FS, Day TA (2002) Response of antarctic terrestrial microarthropods to long-term climate manipulations. Ecology, 83, 3130-3140.

Convey P, Wynn-Williams DD (2002) Antarctic soil nematode response to artificial climate amelioration. European Journal of Soil Biology, 38, 255-259.

Coulson SJ, Hodkinson ID, Webb NR et al. (1996) Effects of experimental temperature elevation on high-arctic soil microarthropod populations. Polar Biology, 16, 147-153.

Coulson SJ, Hodkinson ID, Webb NR (2003) Microscale distribution patterns in high Arctic soil microarthropod communities: the influence of plant species within the vegetation mosaic. Ecography, 26, 801-809.

Dollery R, Hodkinson ID, Jonsdottir IS (2006) Impact of warming and timing of snow melt on soil microarthropod assemblages associated with Dryas-dominated plant communities on Svalbard. Ecography, 29, 111-119.

Dormann CF, Woodin SJ (2002) Climate change in the Arctic: using plant functional types in a meta-analysis of field experiments. Functional Ecology, 16, 4-17.

Førland EJ (1993) Precipitation Normals, Normal Period 1961-1990. Norwegian Meteorological Institute, Oslo, Norway.

Fjellberg A (1974) En studie av collembolfaunaen på Stigstuv, Hardangervidda. Abundans, biomasse og artsdiversitet. (A study of the Collembola fauna at Stigstuv, Hardangervidda. Abundance, biomass and species diversity) (in Norwegian). Unpublished MSc thesis, University of Bergen, Norway, 141pp.

Fjellberg A (1998) The Collembola of Fennoscandia and Denmark. Part I: Poduromorpha. Fauna Entomologica Scandinavica, 35, 1-184.

Fjellberg A (2007) The Collembola of Fennoscandia and Denmark. Part II: Entomobryomorpha and Symphypleona. Fauna Entomologica Scandinavica, 42, 1-266.

Hågvar S (1982) Collembola in Norwegian coniferous forest soils I. Relations to plant communities and soil fertility. Pedobiologia, 24, 255-296.
Hågvar S (1983) Collembola in Norwegian coniferous forest soils II. Vertical distribution. Pedobiologia, 25, 383-401.

Hågvar S (1990) Reactions to soil acidification in microarthropods: Is competition a key factor? Biology and Fertility of Soils, 9, 178-181.

Hågvar S, Kjøndal BR (1981) Succession, diversity and feeding habits of microarthropods in decomposing birch leaves. Pedobiologia, 22, 385-408.

Harte J, Rawa A, Price V (1996) Effects of manipulated soil microclimate on mesofaunal biomass and diversity. Soil Biology and Biochemistry, 28, 313-322.

Hodkinson ID, Coulson SJ, Webb NR (2004) Invertebrate community assembly along proglacial chronosequences in the high Arctic. Journal of Animal Ecology, 73, 556-568.

Hodkinson ID, Coulson SJ, Webb NR, Block W (1996) Can high arctic soil microarthropods survive elevated summer temperatures? Functional Ecology, 10, 314-321.

Hodkinson ID, Webb NR, Bale JS, Block W, Coulson SJ, Strathdee AT (1998) Global change and arctic ecosystems: conclusions and predictions from experiments with terrestrial invertebrates on Spitsbergen. Arctic and Alpine Research, 30, 306-313.

Hole L, Engardt M (2008) Climate change impact on atmospheric nitrogen deposition in northwestern Europe: a model study. Ambio, 37, 9-17.

Hollister RD, Webber PJ (2000) Biotic validation of small opentop chambers in a tundra ecosystem. Global Change Biology, 6, 835-842.

IPCC (2007) Fourth Assessment Report of the Intergovernmental Panel on Climate Change. Cambridge University Press, Cambridge, UK.

Kennedy AD (1994) Simulated climate change: a field manipulation study of polar microarthropod community response to global warming. Ecography, 17, 131-140.

Klanderud K (2008) Species-specific responses of an alpine plant community under simulated environmental change. Journal of Vegetation Science, 19, 363-372.

Klanderud K, Totland Ø (2005) Simulated climate change altered dominance hierarchies and diversity of an alpine biodiversity hotspot. Ecology, 86, 2047-2054.

Kosztarab M, Kozár F (1988) Scale Insects of Central Europe. Junk, Dordrecht.

Kozár F, Miller DR (2000) World revision of Ortheziola Sulc (Homoptera: Coccoidea: Ortheziidae) with descriptions of eleven new species. Systematic Entomology, 25, 15-45.

Lloyd J, Taylor JA (1994) On the temperature dependence of soil respiration. Functional Ecology, 8, 315-323.

Luxton M (1981) Studies on the Oribatid mites of a Danish Beech wood soil IV. Developmental biology. Pedobiologia, 21, 312-340.

Macfadyen A (1961) Improved funnel-type extractors for soil arthropods. Journal of Animal Ecology, 30, 171-184.

Marion GM, Henry GHR, Freckman DW et al. (1997) Open-top designs for manipulating field temperature in high-latitude ecosystems. Global Change Biology, 3 (Suppl. 1): 20-32.

Martikainen E, Huhta V (1990) Interactions between nematodes and predatory mites in raw humus soil: a microcosm experiment. Revue d'Écologie et de Biologie du Sol, 27, 13-20.

McGeoch MA, Le Roux PC, Hugo EA, Chown S (2006) Species and community responses to short-term climate manipulation: 
microarthropods in the sub-Antarctic. Austral Ecology, 31, 719-731.

Mebes KH, Filser J (1998) Does the species composition of Collembola affect nitrogen turnover? Applied Soil Ecology, 9, 241-247.

Nadelhoffer KJ, Giblin AW, Shaver GR, Linkins AE (1992) Microbial soil processes and plant nutrient availability in arctic soils. In: Arctic Ecosystems in a Changing Climate, an Ecophysiological Perspective (eds Chapin FS, Jefferies RL, Reynolds JF, Shaver GR, Svoboda J), pp. 281-300. Academic Press, San Diego, CA, USA.

O'Connor FB (1962) The extraction of Enchytraeidae from soil. In: Progress in Soil Zoology (ed. Murphy PW), pp. 279-285. Butterworths, London.

Ruess L, Michelsen A, Schmidt IK, Jonasson S (1999) Simulated climate change affecting microorganisms, nematode density and biodiversity in subarctic soils. Plant and Soil, 212, 63-73.

Schatz H (1985) The life cycle of an alpine oribatid mite, Oromurcia sudetica Willmann. Acarologia, 26, 95-100.

Seastedt TR (1984) The role of microarthropods in decomposition and mineralization processes. Annual Review of Entomology, 29, $25-46$.

Sinclair BJ (2002) Effects of increased temperatures simulating climate change on terrrestrial invertebrates on Ross Island, Antarctica. Pedobiologia, 46, 150-160.

Sinclair BJ, Stevens MI (2006) Terrestrial microarthropods of Victoria Land and Queen Maud Mountains, Antarctica: implications of climate change. Soil Biology and Biochemistry, 38, 3158-3170.

Sjursen H, Michelsen A, Jonasson S (2005) Effects of longterm soil warming and fertilisation on microarthropod abundances in three sub-arctic ecosystems. Applied Soil Ecology, 30, 148-161.

Solhøy T (1975) Dynamics of oribatei populations on Hardangervidda. In: Fennoscandian Tundra Ecosystems. Part 2. Animals and Systems Analysis (ed Wielgolaski FE), pp. 60-65. SpringerVerlag, Berlin.

Tilrem L (1994) Life history traits in two Oribatid mites (Ameronothrus lapponicus Dalenius and Phauloppia sp.) in an extreme high mountain habitat. Unpublished MSc thesis, University of Bergen, Norway.

Verhoef HA, de Goede RGM (1985) Effects of collembolan grazing on nitrogen dynamics in a coniferous forest. In: Biological Interactions in Soil (eds Fitter AH, Atkinson D), pp. 367-376. Blackwell Scientific Publications, Oxford.

Wallwork JA (1970) Ecology of Soil Animals. McGraw-Hill, London.

Walter DE, Proctor HC (1999) Mites. Ecology, Evolution and Behaviour. CABI Publishing, Wallingford, Oxon, UK.

Webb NR, Coulson SJ, Hodkinson ID, Block W, Bale JS, Strathdee AT (1998) The effects of experimental temperature elevation on populations of cryptostigmatic mites in high Arctic soils. Pedobiologia, 42, 298-308.

Weigmann G (2006) Hornmilben (Oribatida). Die Tierwelt Deutschlands, 76, 1-520.

White A, Cannel MGR, Friend AD (1999) Climate change impacts on ecosystems and the terrestrial carbon sink: a new assessment. Global Environmental Change, 9, 21-30.

Ytrehus B, Bretten T, Bergsjø B, Isaksen K (2008) Fatal Pneumonia Epizootic in Musk ox (Ovibos moschatus) in a period of extraordinary weather conditions. EcoHealth, 5, 213-223. 